\title{
INTO AND OUT OF CITIZENSHIP, through Personal Tax Payments
} Romanian Migrants' Leveraging of British Self-Employment

Dora-Olivia Vicol

\begin{abstract}
This article builds on observations of self-employed Romanian migrants and their encounters with UK fiscal obligations to position tax as a distinct node in the worker-citizen nexus. Speaking to anthropological critiques of neoliberalism, I argue that economic activity is not merely the ethical imperative of a political order premised on self-reliance. It is also a practical test of migrants' abilities to translate the moral capital of 'hard work' into the categories and bureaucracy of fiscal contribution. Analyzing migrants' compliance with immigration controls and fiscal regimes, seen as a duty to 'account for oneself' in moral and financial terms, this article theorizes tax returns as a key junction in the workercitizen nexus-one that can allow migrants into, but also confine them to the margins of, European citizenship.
\end{abstract}

Keywords: citizenship, migration, neoliberal governance, Romanians, selfemployment, tax

Anthropology rests upon a long tradition of critical inquiry into entrepreneurial citizenship. Since the 1990s, a burgeoning anthropology of neoliberalism has examined the ways in which measures purportedly adopted to stimulate individual autonomy, in the spirit of classical liberalism, have coincided with a marketization of governance, in the spirit of neo-classical economics (Ganti 2014; Makovicky 2016). Across ethnographies of work (Chelcea 2015; Urciuoli 2008) and job seeking (Gershon 2014, 2016; Van Oort 2015), scholars have illustrated how appeals to self-reliance couched in 'can do' language can obfuscate precarity (Muehlebach 2013), yet, similarly, how self-sufficiency can enable workers to narrate themselves as meaningful subjects in moral orders premised on economic contribution (Millar 2014). A similar ambivalence characterizes 
European citizenship and the story of Romanian migrants who informed this article. If, in a juridical sense, all Romanians became European citizens, free to move across the member states the moment Romania acceded to the EU, at a discursive level even a cursory look at the press illustrates how Romanians' mobility was not welcome but merely tolerated to the extent that they proved themselves 'good workers' (Anderson 2015; McGhee et al. 2019).

Despite the attention devoted to self-sufficiency as a neoliberal imperative, less scrutiny has been dedicated to how work mediates access to substantive citizenship in practice through tax. The literature that documents autonomous work points to the moral dominance of economic activity, but leaves much unsaid about how this is deployed to secure residence, access welfare, or obtain any of the other everyday protections that de facto constitute citizenship (Currie 2016). Correspondingly, within the mobilities literature there is also much unsaid about how intra-European migrants leverage their economic contribution to access the protections of host states. This, I argue, is an important oversight. Economic activity is more than a discursive tool deployed to distinguish between the deserving and the undeserving in public debate. It is also a process with a fiscal materiality that can open the path to substantive citizenship, or can confine migrants to European citizenship in name only.

This article addresses this gap in the theorization of tax by investigating how Romanian migrants navigated their fiscal obligations. Building on the literature that examines the discursive prominence of economic activity in what scholars call the 'worker-citizen nexus' of neoliberal governance (Anderson 2015), I shift the focus to the frictions of material bureaucracies, networks, and interpretive frameworks that mediate tax contributions in the everyday.

To illustrate this, the article draws attention to three concepts. First, I conceptualize the obligations that migrants derive from EU mobility and fiscal regimes as a duty to 'account for oneself'. Drawing on the "dual credentials" of accountability identified by Strathern (2000: 1) - as moral reasoning on the one hand, and as a method of bookkeeping inspired by financial accountancy on the other-I argue that the tolerated status of Romanians is dually conditioned: on their readiness to constitute themselves as 'hard workers' and on their ability to fashion themselves as financial entities.

Building on this observation, the second point this article makes is to conceptualize tax payments as a relational practice. Despite the appeals to selfreliance inherent in neoliberal citizenship, I show how entering the rungs of taxpayers was, in effect, a highly mediated process shaped by a lucrative industry of migration consultants (Gammeltoft-Hansen and Sørensen 2013; Garapich 2008) and street-level bureaucrats (Lipsky 1980) who had the power to validate or reject Romanians' attempts at bookkeeping.

This brings the article to its third and final point. Looking at how Romanian migrants mobilized, and were immobilized, by their tax obligations, I show 
how personal accountancy could bring them both into and out of substantive European citizenship. For those who mastered the format of bookkeeping, taking up self-employment could allow access to welfare, student finance, and employment rights. For those who could not, however, exclusion from taxation meant being relegated to the margins, which left them vulnerable to immigration controls and the abuse of unscrupulous employers. The article concludes with a call to conceptualize tax contributions as a personal technology that can help migrants move from the periphery to the core of citizenship.

The fieldwork that informed this article was conducted in several stages, including a year of participant observation during my doctoral study of Romanian networks, from September 2014 to September 2015, and subsequent interviews with four families of Romanian Roma scattered between the autumn of 2017 and the spring of 2019. A key component of the project was the three months I spent volunteering as an employment rights caseworker. Many attendees were laborers, cleaners, and other 'gig economy' workers who hoped to start legal battles against unpaid fees. Assisting them effectively meant observing their struggles to position their everyday work within the tax paymentlegal protection exchange that underpins formal citizenship. There could be no legal battle without citizenship, and no claim to citizenship without a proven record of tax payments. Piecing this record together, at times quite literally by sifting through the letters that attendees had kept but could not decode, provided an important insight into how Romanians struggled to understand and fulfill the fiscal obligations of self-employment. During this stage of fieldwork, I conducted 24 interviews, 6 with clients I had personally assisted. Equally significant was the time I subsequently spent in a North London neighborhood observing migrants' interactions with acquaintances and paid-for consultants who were called upon to translate their fiscal duties-and who straddled the boundary between profiting and caring.

Overall, my fieldwork in London included interviews and observations that involved 70 Romanian migrants. These were men and women who had just a few months or several years of experience in the UK, who had migrated from impoverished villages in search of economic opportunity, or who had left materially comfortable positions in order to explore a different kind of living. What they shared was a duty to affirm themselves as taxpayers in a worker-citizen regime that tolerated their residence, but conditioned their substantive citizenship on fiscal contributions.

\section{Placing Tax in the European Worker-Citizen Regime}

Tucked at the end of the Northern Underground line in one of the northernmost London suburbs, Little Moldova is a cacophony of supermarkets, beauty salons, 
and small eateries that display the blue, yellow, and red Romanian tricolor. ${ }^{1}$ Scattered along the high street, they serve a community whose population in the city had grown from 14,000 at the time of European accession in 2007 to as many as 119,000 the year I started fieldwork (APS 2018). Together, the Romanians of Little Moldova speak the second most popular language in that area of London. They are part of a migrant group with one of the highest rates of selfemployment in the UK (Vargas-Silva and Fernández-Reino 2019), whose right to reside, work, and enjoy the protections of their host state as European citizens is conditioned on their ability to fashion themselves as independent taxpayers.

Romania joined the EU 18 years after the toppling of Nicolae Ceauşescu's socialist regime. For many Romanians, joining Europe meant inching closer to normalcy, after a 'transition' marked by power struggles, corrupt property seizures, and widening inequalities (IQLR 2017). Polled in 2007, Romanians had among the highest levels of support for EU membership (European Commission 2007). In theory, joining the EU would grant them European citizenship and with it the right to move to and work in other members states, and to access their protections without discrimination. This was enshrined in the Maastricht Treaty of 1993 and subsequently refined as a core pillar of European integration (Mindus 2017).

Despite these expectations, however, both the process of accession and the citizenship it conferred were more fraught. From the moment negotiations were opened, Romania struggled to shake a 'laggard' status. Pointing to corruption and deficiencies in public administration, commentators doubted the extent to which Romania and Bulgaria, who joined the same year in what became known as the 'A2 accession', were allowed membership on the basis of actual reform, or were simply being tolerated out of an ideological commitment to absorb the post-socialist bloc (Gallagher 2009; Papadimitriou and Phinnemore 2008). It is not surprising, perhaps, that the $A 2$ accession started with another transition, characterized by limited entitlements.

Imposed from 2007 to 2014, the transitional regime gave Romanians and Bulgarians the right to travel and live across the European Economic Area for three months, but restricted their right to reside beyond that grace period (UKBA 2008). Students registered at British universities or colleges were allowed in the country and could take part-time work, but were largely denied access to benefits. Waged employment was available to the few applicants who were young, educated, and wealthy enough to qualify for a 'highly skilled' permit; otherwise, it was restricted to a niche of undersubscribed occupations, such as agriculture or food processing. There was also an option of 'self-sufficiency', which granted A2 nationals lawful residence, but not the right to work or access welfare. For everyone else-that is, most ordinary migrants-making a living in the UK or any of the other member states that upheld the transitional regime meant working as self-employed contractors: they would be allowed access to 
residence, public services, and welfare support, but would be required to find their own work and manage their own tax contributions. By 2014, as many as 59 percent of Romanians and Bulgarians were registered as self-employed, regardless of training, original aspirations, and indeed their ability to navigate the fiscal requirements of this status (Migration Observatory 2014).

A vast body of literature has critiqued the moral deficiencies of conditioning European citizenship on economic self-sufficiency. Scholars of mobility have argued that despite the framing of enlargement as a symbolic return, transitional arrangements, in effect, institutionalized second-class status for the East (Bruzelius et al. 2017; Kochenov 2006). Intra-European migrants, Anderson (2015) argues, are 'tolerated citizens' to the extent that they make 'good workers', in the same way that Britons are relegated to the rungs of failed citizenship if they become economically inactive. This is compounded by critiques highlighting the institution of self-sufficiency that exists at the heart of neoliberal citizenship more broadly. The requirement of economic independence, which is so visible in immigration controls, is not only a feature of transitional controls imposed on Romanians and Bulgarians, but also an aspect of neoliberal governance (Chandler and Reid 2016; Rose 1999).

Turning their attention to these measures, anthropologists have documented the systems of knowledge, administration, and representation that make living one's life an enterprise. Looking at the creation of workers' subjectivities, ethnographers have examined how CV writing and career counseling workshops promote a fashioning of the self as a business (Gershon 2014, 2016; Larson 2008), how performance reviews and team-building exercises colonize personal time (Adkins and Lury 1999; Chelcea 2015), and how audit cultures impose a logic of accountancy on everyday life (Power 1997; Strathern 2000).

It is puzzling, therefore, that despite the interest in entrepreneurial selfmaking, becoming a self-sufficient citizen in practice through the medium of tax remains overlooked. Existing literature notes that transitional migration controls created particular types of economically active migrants (Anderson 2010, 2015; McGhee et al. 2019). Yet for all the discursive weight associated with being seen and narrating oneself as a 'good worker', the leap from tolerated residence to substantive citizenship is conditioned on migrants' ability to credibly translate their autonomy into a fiscal footprint. A first theoretical ambition of this article is thus to position taxes as a junction that can make or break the worker-citizen. To this end, I build on a number of interventions in the social study of tax (Campbell 1993; Martin and Prasad 2014).

Inspired by Schumpeter's early-twentieth-century observation that tax collection lays at the foundation of the modern state, Martin et al. (2009) propose a fiscal sociology that shifts attention from questions of revenue collection, distribution, and economic performance to how tax shapes the social contract. Steeped in historically constituted notions of value, taxation not only formalizes 
the relation between citizen and ruler, but also provides a means of demanding social change-an angle that has been explored in a small number of anthropological works. Looking at the Swedish tax authority's attempts to engineer compliance, Björklund Larsen (2017) draws attention to the ways in which tax contribution is used to affirm a particular national character, marked by moderation and collective welfare. Taxes, she concludes, are not just about the collection of revenue, but about the fashioning of moral and political orders. It is in the same vein that other ethnographers locate tax avoidance as a form of joint fiscal and political disobedience. Withholding contribution, it is argued, can act as a critique of an unjust state and inequitable market relations (Guano 2010), and as an affirmation of alternative value systems (Roitman 2007).

This article furthers the anthropology of tax by drawing attention to its everyday materiality. While existing investigations into fiscal regimes go far to position taxation as a site of ethical negotiation, there is much left to be said about the processes, aesthetics, and relations through which tax payments are enacted. Despite any alignment of values, it is a migrant's ability to navigate the infrastructure of tax contributions that enables, or frustrates, his or her access to substantive European citizenship. A second ambition of this article is to move us away from questions of value negotiation among those who are citizens and instead draw attention to how tax allows one to become a citizen-through particular bureaucratic processes and aesthetics of numerical self-fashioning.

\section{Accounting for Oneself: The Categories and Aesthetics of a Personal Business}

On my first week as a caseworker, I met Ion. Almost 60 years old, with the imposing build of a man who had done physical work for decades, he sat nervously on the small chair by the adviser's desk. Like many of the charity's cases, his was an issue of non-payment. Ion was a carpenter for a small construction company and was owed over $£ 700$ (\$886) for a week's work. His breathing quickened as described the "humiliation" of trying to claim what he was owed. Having mastered only a few words in English, he had to argue with a man who was half his age, but twice as brazen. He was threatened with violence and collapsed.

We tried to calm Ion down, reverting to the small comfort of procedure. As with every case of a work dispute, the first step was to determine whether Ion was an employee, which could lead his case to the Employment Tribunal, or whether he operated as a self-employed contractor, which would end with a case at the Small Claims Court. When I asked the question, the term 'employment status' did not bring a response. Recently taught by more senior colleagues that it was we, the advisers, who would likely determine clients' status, 
I then asked if I could view any documents related to the job. Within moments, the desk space between us was covered with a collection of letters that Ion had pulled out of a bundle packed tightly inside his wallet. As he unfolded them attentively, I looked for pay slips or letters from the tax authority (HMRC) as clues to his employment status. ${ }^{2}$ There were none. Ion's ‘documents' consisted mostly of handwritten notes on which he had tracked the hours and tasks he had been assigned at work. Other than those, Ion revealed, his name did not appear on any records of the job at all.

“There wasn't a day from God that I didn't work," Ion remarked. For more than a decade before coming to London in 2012, he had traveled to Israel, Italy, and Ireland, taking on "every construction job there was." A Pentecostal father of eight children, it was his remittances that kept the family "wanting for nothing." His children, some adults by now, had finished school; his wife had learned to drive a good German car. Yet when we met at the charity, it became clear that the autonomy he affirmed with poise had failed to translate into a record. For reasons he could not quite determine, Ion had never been able to convince clerks who interviewed him for a social security number (known in the UK as a National Insurance number or NINO) that the work arrangements he secured as a carpenter amounted to 'genuine' self-employment. Without a NINO, in turn, he could not apply for the Unique Tax Reference Number (UTR) needed to register his self-employment with the tax authority. And without any communication from government agencies to count as proof of address, he was not able to get a bank account. In an arrangement mutually agreed upon with the company, Ion made do by receiving payment through the account of a friend who worked on the same project. "What about taxes?" I asked. Ion shrugged. Perhaps the friend would pay those, too, and they would square the debt later.

The story of Ion captures a paradox I encountered repeatedly. Acquainted with the skepticism that had surrounded Romanian migration in the British press and Western European media more broadly (Vicol and Allen 2014), many of the people I interviewed framed their mobility with impassioned affirmations of their work ethic. At the charity and in Little Moldova, men and women stressed their ability to "work hard" and "learn anything," to make the best of the jobs available, and "always to look ahead." There had been moments of anxiety when payments were not honored and when short-term engagements ended abruptly. Operating in a regime described as 'dependent' self-employment (Böheim and Muehlberger 2006), often in positions that were poorly paid and devoid of the protections inscribed in the employment contract, insecurity was common-particularly for women, who experienced lower pay rates and fewer opportunities for upskilling (Parreñas 2015). Nonetheless, like generations of migrants who had learned to frame their right to belong through active economic contribution, people like Ion narrated their mobility 
with affirmations of work ethic, whether in interviews with myself and charity workers, or in everyday conversations whenever migration came up.

Despite their accounts of personal autonomy, however, many Romanians struggled to navigate the technical barriers required to translate self-sufficiency, which they valued and experienced, into the fiscal contribution required to access the entitlements of European citizenship. At this point, a discussion of the material bureaucracy of taxation becomes relevant. Unlike wage workers, whose income tax and social security contributions are processed by employers, the self-employed must manage their taxes individually. Once a year, sole traders $^{3}$ are prompted to $\log$ in to an online platform, where a menu several pages long asks them to assess their income, declare any expenditures and losses incurred, and then pay the tax indicated by the program directly into the account of the fiscal authority.

This is where accounting for oneself became a technical challenge. The majority of Romanians who took up this status were not IT-savvy business owners; rather, they were ordinary migrants for whom self-employment was simply the easiest means of earning an income legally. Some of them, like Ion, were farmers with just eight years of education, who had previously made a living in manual occupations. There was hardly a question of operating laptops and accessing the digital infrastructure that mediated tax payments in the UK. Nor was there a 'bureau' where one could even see the tax authority. In a country that had made a mission of digitizing citizenship, whether national or European, becoming a taxpaying citizen was, in practice, a test in decoding the interface of the HMRC.

A second, and arguably more confounding, aspect was that paying taxes was a test not only in reading the state, but also in making oneself legible through the tax authority's categories. This is where a discussion of the dual valences of accounting becomes illuminating. In a seminal intervention, Power (1997) drew attention to the ways in which the practice of auditing, derived from finance, has become a ubiquitous tool of neoliberal governance. Building on his critique, Strathern (2000) observed how accountability, in the moral sense, is increasingly reduced to a question of accountancy inspired by the quantitative language of finance. By situating moral worth within the categories of financial accountancy, Strathern argued, 'audit cultures' pose the risk of crushing the ethic they purport to defend. They place the burden of fitting life into financial categories upon the shoulders of the form filler, while leaving the rigidities of the form unquestioned (ibid.).

It is in this vein that self-employment entails a translation of the self-the living person who works, moves, earns, and spends-into the language of the tax authority. At a minimum, it means monitoring earnings by providing dated invoices, isolating everyday purchases into tax-deductible expenses, and always keeping a record of receipts. Such tax-minded records are required at 
every annual payment of income tax and social security, like a ritual of confirming one's status. Paradoxically, however, in the case of Romanian migrants this level of self-accountancy was also required at the very entrance into citizenship, in their applications for a social security number.

Unlike British nationals, who are granted a NINO before they begin work and are required to pay any tax (usually by their sixteenth birthday), the transitional immigration controls conditioned the receipt of a NINO on Romanian migrants' ability to reproduce the protocols of a taxpaying business. Accounting for oneself was thus a semantic translation of lived autonomy into the categories of financial accountancy. It also meant adopting a certain aesthetic through which such translations became recognizable to the bureaucrats who wielded the power to allow or reject migrants from the rungs of NINOholding, taxpaying European citizens in the UK. Just like Ion, no A2 migrants, however keen to affirm their self-reliance, could exercise the entitlements of European citizenship unless they also attended an interview and convinced the person at the National Insurance desk that their records reflected 'genuine' autonomous work.

Ethnographers of bureaucracy have amply theorized the persuasiveness of form (Strathern 1991). As 'graphic artifacts' (Hull 2003), documents derive their authority from the substance of their text as much as from the design and type fonts that constitute their surface (Hull 2012; Riles 1998). Studies of bureaucracy since Weber ([1946] 1991) have examined the ways in which mechanized printing, stamps, and letterheads reify the authority of the state by erasing traces of individual authorship. In my informants' case, the challenge was to fill the categories of accountancy as defined by the state with forms that remained open to myriad interpretations.

Having seen several cases where 'documents' came in the form of heterogeneous bundles of bills and faded handwritten notes, the charity had turned record-keeping into a staple of advice. We coached attendees on how to use preprinted booklets to record income and expenditures, how to get their clients to sign and date agreements, and always to put their work arrangements in writing. Thinking of documents as artifacts of authority, imposing in their aesthetics as much as they were in their semantics (Hull 2003; Riles 2000), we taught migrants to buttress the autonomy they valued with the format that would persuade. To be self-employed was to construct and maintain a formatted self.

However, despite the conviction with which the charity promoted getting work arrangements in writing, the advice was a matter of imagination rather than precedent. While the imperative to keep some records was clear enough, there was no single template for how to write an invoice, how to store expenses, or how exactly to make oneself look like a business. Among the caseworkers, our lessons in record-keeping were derived in Weberian fashion from 
the common-sense assumption that a document is more authoritative when it appears more impersonal, that is, when it is recorded in an invoice book or, ideally, computer-processed. For their part, migrants' attempts at accounting for themselves were embroiled in a patchwork of information acquired from friends and a sprawling consultancy industry. It is to this relational nature of taxes that I now turn.

\section{The Relational Nature of Personal Accountancy}

On the high street of Little Moldova, dotted between the shops stacked with Romanian produce, two accountancy offices advertised their services to passersby: "NINOs," "UTRs," and "Tax Returns" appeared at the top, with "Benefit Applications" in small print. With signage in Romanian professionally etched into shop windows, they were the go-to source of information for migrants who, like Ion, struggled to navigate their own fiscal duties, but who, by contrast, could afford to pay for advice. Many more consultants appeared in the rent-free space of social media, where sites such as "Romanians in London" abounded with advertisements for accountancy (contabilitate).

"They fully depend upon me," said Andrea, a 37-year-old law graduate who made a living from consultancy, when referring to her extensive client list. For the past four years, Andrea had assisted more migrants than she could remember. "I never imagined this would be what I would end up doing," she explained. Andrea was not a qualified accountant, but an ambitious graduate who had learned the intricacies of accountancy out of necessity when she turned her casual babysitting engagements into something that looked like a business. The services she provided had started as free advice for friends and migrants whom she empathized with, acquiring a monetary dimension only when she started encountering financial difficulty. She was still unsure of how to define her work and just how much she could reasonably charge clients who had come to rely on her. And yet, in their eyes, she was "the family lawyer."

A veritable market of private 'street-level' (Lipsky 1980) consultants had developed in response to Romanian migrants' fiscal difficulties. Like the "lawyers ... fixers and brokers who sustain links with origin and destination countries" (Cohen 2008: 145) in what the mobilities literature calls a 'migration industry', the consultants of Little Moldova had made a lucrative business mediating migrants' entry into citizenship (Garapich 2008). Firms with busy high street premises advertised services ranging from $£ 150$ (\$190) for NINO applications to $£ 800(\$ 1,013)$ for full tax returns. Consultants like Andrea, by contrast, operated in an ambiguous space of familiarity more akin to favors (Henig and Makovicky 2016), where transactional exchanges were paralleled with appeals to care, and where the client-expert relation intersected with a language of moral 
responsibility. They were not micro-businesses, Andrea explained, but "people who depended on her." She, in turn, was someone who imparted advice over the telephone and often around her clients' dining tables-drawing on a mix of information and educated guesswork that straddled the line between what she knew had to be done and what they all heard, suspected, or imagined that bureaucrats with the power to issue NINOs might like to hear.

I found it fruitful to examine how, in their applications for NINOs, Romanians engaged in veritable performances of personal accountancy. Unlike advisers at the charity, who placed their faith in the authority of the typed record, Andrea's advice for NINO applications extended to how her clients should carry themselves, answer questions, and conform, with subtle details of register and intonation, to clerks' expectations of propriety. "It was an exercise in creativity," stated Marian, a 25-year-old international relations graduate when describing his preparations for the interview and the multitude of acquaintances who contributed to the process.

Getting the NINO was like playing the lottery. You would call some friends and ask them to write some references for you. Right, so let's say, "On the 1st of March Marian painted a room, it was great, I paid him this much, in cash." It had to be cash! Then you'd get another friend to say, "On March the 10th Marian painted a fence," then the same story, cash payments. The referees ${ }^{4}$ chose English names for themselves, because we all thought that a Romanian name would trigger suspicion ... It was an elaborate project, people really used their imagination.

The use of English names in Marian's account speaks volumes about how he imagined the desirable migrant worker-as a subject who was autonomous enough to take up self-employment, yet unthreatening to the hierarchy that positioned Eastern European migrants as providers of labor, and UK natives as its recipients. In a climate of hostility where everyone had some experience of arbitrary rejection, the opaqueness of administrative decisions appeared to give free rein to exercises in forgery and imagination, as Marian put it. Applicants looked for the winning combination of aesthetics and semantics associated with 'proper' accountancy. Becoming a taxpayer, it seemed, was a joint test in financial literacy and in a migrant's ability to reproduce the figure of the hardworking Eastern European migrant.

Far from the individualism inherent in the neoliberal ethics of running oneself like a business (Gershon 2016), for migrants the fiscal practicalities of self-employment involved a multitude of friends, advisers, and street-level bureaucrats, who were called upon to moderate the novelty of this status. Despite narrating themselves as fast-learning, hard-working individuals, no one was quite as self-reliant when it came to tax. Notably, the relations Romanians mobilized in getting a social security number could make the difference 
between those who wedged their way into European citizenship and those who found themselves precariously confined to its margins.

\section{Into and Out of Citizenship}

Falling below the fiscal radar had profound consequences for the quality and security of Romanians' stay in the UK. Those who wished to continue their studies could not qualify for maintenance grants unless they could demonstrate three years of 'ordinary residence', free from immigration restrictions (SFE 2016). Women who wanted to give birth and any patients who appealed to the National Health Service (NHS) were liable to pay for the costs of treatment, although this was not always enforced. There was no question of accessing contributory benefits such as sickness or maternity pay, which were financed from National Insurance, and little hope of accessing a more stable position, since employers usually asked prospective job seekers for a NINO. Perhaps most notably, without a right to reside demonstrated by a history of tax contributions, Romanian migrants were, in effect, 'illegalized' (De Genova 2002) - that is, rendered vulnerable to administrative removal, which entailed temporary deportation and a year-long ban on re-entry. According to Home Office (2018) figures, in 2014 there were 1,024 enforced returns for A2 nationals.

In the North London borough of Brent, in close vicinity to Little Moldova, immigration officers routinely joined the metropolitan police during enforcement raids. A Public Space Protection Order, instituted by local councils in areas flagged for 'anti-social behaviors', gave officers the power to approach virtually anyone who appeared suspicious. I joined one operation as a reporter for a local Romanian publication. Our session started with a briefing at the station just before the break of dawn. By lunchtime, the route would cover parks where the council had received reports of homeless sleepers, streets signaled for unlicensed multiple occupancy, and crossroads where men congregated in search of temporary construction work.

Although the operation was ostensibly aimed at behaviors and not people, its subjects were invariably Romanian men-standing in groups on the pavement or simply walking, but looking too poor, too disheveled, and too dark to remain unnoticed. The van would pull over abruptly, allowing the police to rush out. Aided by a single Romanian-speaking officer, the crew would ask those they interrogated for identification, record dates of arrival, and hand notices of temporary dispersal. The Home Office team, for its part, would move on to interrogate those migrants who had exceeded the three-month grace period and were legally required to prove their right of residence. IDs were retained, and names were taken. As officers returned to their vans, the migrants were left with notices warning that a failure to produce convincing proof of taxpaying work 
in the future would trigger administrative removal. By the end of my fieldwork, two of my informants found themselves in such a situation.

A substantial body of mobility scholarship has examined how bordering processes have encroached on the interstices of the everyday (De Genova 2002; Yuval-Davis et al. 2018). Informed by notions of citizenship based on race, class, and gender, which are refracted through the eyes of officers on the front line, borders are theorized as the spaces where alterity is intercepted, and its bearers are positioned in or outside the perimeter of the state. In my informants' case, tax contributions were what exposed or shielded them from the full force of this regime. Although being a taxpayer was unlikely to make one less visible to the gaze of Home Office enforcement looking to deport the homeless, having this status could, in a small and tactical fashion, anchor migrants into a space of tolerated citizenship-not openly welcome, but technically entitled to state protections. I find it fitting, therefore, to conclude this exploration of migrants' tax obligations with a narrative that demonstrates how personal tax returns could open a new path to citizenship, moderating both the intervention of enforcement officers and the machinations of employers who pushed their staff into illegality by refusing to formalize their status.

It was a cold January morning when I met 19-year-old Cristina at a corner shop in Little Moldova. She was hovering by the till at the beginning of a 12-hour shift, keeping one hand warm in her vest while the other reached for her breakfast tucked under the counter, to be eaten during the few moments of respite she had in between customers. Similar to many of the women working in the area, Cristina had started her job as a cashier with the help of her partner, who had asked a neighbor to ask an older brother to find her a foothold abroad. She was young, inexperienced, and indebted to the network of men who, she thought, had done her the great favor of "pulling [her] abroad" at a time when many young people from her village were looking for similar opportunities. In the year since her arrival, she had worked for a business that paid her $£ 4$ (\$5) per hour without an employment contract, resulting in a state of complete fiscal invisibility. Wishing to avoid the costs of payroll, her boss had pushed Cristina and the other staff into an informal arrangement that left no record of their work in the ledgers of the tax authority, thus depriving them of the right to lawful residence.

Over the year I had come to know Cristina, I observed how grievances about the cold, pay, and insecurity of her employment were silenced by the feeling of indebtedness. She had come to learn from well-meaning customers that without an employment contract her status in the UK was uncertain; but the expense and embarrassment of challenging the men who had helped her migrate made the thought of legal action unfathomable. It was in this sense that registering for self-employment offered her, and others who felt burdened by the weight of favors past, a fiscal 'weapon of the weak' (Scott 1985). 
Without her boss's knowledge, Cristina appealed to a consultant. She had a social security number that her boss had helped her obtain, but never paid into, so all it took was to call the HMRC. With her adviser by her side, she claimed to a clerk that she had worked independently for an entire year while waiting for "the documents" to arrive. When the time came, the same adviser would walk her through the digital platform and, for a fee, help her pay the income tax and National Insurance contributions that her boss had evaded for more than a year. Backdating her claim to self-employment enabled Cristina to legalize her status post factum. It opened access to a student maintenance grant, which later enabled her to take a course in business administration. Other women in Little Moldova recounted tactically registering for self-employment to avoid paying NHS fees and, more recently, to qualify for 'settled status' after Brexit.

There was little fairness in the fact that migrant women who were young, poor, and rendered vulnerable by the tactics of unscrupulous men could see no option but to pay their own way into European citizenship. Nor was there justice in the classed and racial way that Romanian men were seized in police raids. However, once we untangle the regimes of tax, work, and residence that characterized the stay of Romanians in the UK, it becomes apparent that taking ownership of one's fiscal status could shield migrants from the excesses of powerful individuals and allow them to access the protection of the state. However costly, voluntary tax contributions enabled women like Cristina to carve a new path into substantive European citizenship, and they could have allowed the laborers in North London to secure a right of residence when Home Office raids singled them out. As a distinct node, with a material, aesthetic, and relational nature of its own, tax contributions can make or undermine the worker-citizen in ways that go beyond the ethic of self-sufficiency. Accounting for oneself through tax payments could open Romanian migrants' way to substantive citizenship regardless of the dependent nature of their employment, in the same way that failing to make a tax contribution could cast them out, despite their claim to "work hard, and always be looking ahead.”

\section{Conclusion}

Reflecting on the nascent anthropology of tax, I find it useful to consider how tax payments render citizenship malleable. Through a closer look at the fiscal duties associated with self-employment, I have proposed a conceptualization of taxation as a terrain of practice that links, in imperfect ways, the moral requirement of economic contribution with the entitlements of substantive citizenship. I have argued that the business-like self-reliance that lies at the 
heart of neoliberal governance is not a mere discursive artifice, but also a quotidian means to render oneself legible to the state as a fiscal contributor. Beyond the narratives of hard work observed during my fieldwork, and even the existence of autonomous work arrangements, the citizenship regime that characterized Romanians' mobility was also a test of their ability to master the format of accountancy and to reproduce a credible image of diligent tax contributors in their encounters with gatekeepers who could grant or withhold state protection.

In this sense, paying tax was inextricably involved in acquiring, or being excluded from, the entitlements of European citizenship-the right to live without fear of deportation, to access education, and to thrive. For migrants, failing to construct oneself as an independent taxpayer left the poor, the digitally illiterate, and those who could not navigate the format of tax returns vulnerable to British immigration enforcement officers. It created spaces of differentiated citizenship where migrants' appeals to self-sufficiency did little to mitigate the lack of access to welfare and the very real risk of deportability. Yet unexpectedly and at the same time, becoming a taxpaying subject gave Romanians a means of wedging their way into citizenship when immigration controls restricted other forms of lawful residence, and when unscrupulous bosses denied them formal employment.

Emerging investigations into taxation are already beginning to draw attention to its prominent role in the social contract, and to its power to moderate moral orders. No doubt, there are few policies that match the level of public interest generated by changes to taxation. Beyond the realm of the discursive, however, I find it useful to consider fiscal regimes as material infrastructures that silently underscore citizenship in ways that do not always map onto the moral imperatives affirmed in public debate. The self-employed Romanian migrants I observed could mobilize, but they were also immobilized by their fiscal obligations-regardless of the work they had conducted or their selfaffirmation as deserving entrepreneurs. If an anthropology of tax positions fiscal obligations at the heart of the modern social contract, a look at personal tax payments sheds light on instances when migrants may be able to write themselves into the contract, or be quietly erased out of it. 


\section{Acknowledgments}

The author would like to thank the UK Economic and Social Research Council for funding the doctoral project with Romanian migrants that informs this article, as well as the ETHOS project funded by the European Union's Horizon 2020 program (Grant Agreement No. 727112) for enabling further data collection with Romanian Roma migrants.

Dora-Olivia Vicol completed her PhD in Anthropology at the University of Oxford's Centre on Migration, Policy and Society, and moved to a postdoctoral position in the Centre for the Study of Migration at Queen Mary University of London. With an empirical focus on low-skilled migrant communities in London, her work examines everyday negotiations of mobility in encounters with bureaucrats and employers drawn into the bordering process. In 2016, Olivia co-founded the Work Rights Centre, a UK-based charity dedicated to employment rights, and is its Acting Director. Since then, her theoretical interest in mobility regimes has been fused with an active engagement in charity. E-mail: olivia.vicol@workrightscentre.org

\section{Notes}

1. Little Moldova is a colloquial term that some informants used for this area of London (described in my doctoral thesis as 'The Neighbourhood'). It refers to the Romanian province of Moldova, where many of them came from, rather than the Republic of Moldova. Informants' names have been changed, and translations are my own, unless otherwise indicated.

2. The HMRC (Her Majesty's Revenue and Customs) is the department of the UK government that assesses and collects taxes, pays some forms of support to citizens, and administers other regulatory programs.

3. 'Sole traders' is a technical term used by the HMRC to refer to the subset of self-employed individuals who do not subcontract anyone else.

4. In the UK, a 'referee' is a person who testifies in writing about the character of someone, especially when that person is applying for a job.

\section{References}

Adkins, Lisa, and Celia Lury. 1999. "The Labour of Identity: Performing Identities, Performing Economies.” Economy and Society 28 (4): 598-614.

Anderson, Bridget. 2010. "Migration, Immigration Controls and the Fashioning of Precarious Workers.” Work, Employment \& Society 24 (2): 300-317. 
Anderson, Bridget. 2015. "Immigration and the Worker Citizen." In Citizenship and Its Others, ed. Bridget Anderson and Vanessa Hughes, 41-57. Basingstoke: Palgrave Macmillan.

APS (Annual Population Survey). 2018. "Population by Country of Birth-Detailed Country of Birth-London.” London Datastore. https://data.london.gov.uk/ dataset/country-of-birth.

Björklund Larsen, Lotta. 2017. Shaping Taxpayers: Values in Action at the Swedish Tax Agency. New York: Berghahn Books.

Böheim, René, and Ulrike Muehlberger. 2006. “Dependent Forms of Self-Employment in the UK: Identifying Workers on the Border between Employment and Self-Employment.” Discussion Paper No. 1963. IZA Institute for the Study of Labor, Bonn.

Bruzelius, Cecilia, Constantin Reinprecht, and Martin Seeleib-Kaiser. 2017. "Stratified Social Rights Limiting EU Citizenship.” Journal of Common Market Studies 55 (6): 1239-1253.

Campbell, John L. 1993. "The State and Fiscal Sociology.” Annual Review of Sociology 19: 163-185.

Chandler, David, and Julian Reid. 2016. The Neoliberal Subject: Resilience, Adaptation and Vulnerability. London: Rowman \& Littlefield.

Chelcea, Liviu. 2015. "Post-Socialist Acceleration: Fantasy Time in a Multinational Bank.” Time \& Society 24 (3): 348-366.

Cohen, Robin. 2008. Global Diasporas: An Introduction. 2nd ed. London: Routledge.

Currie, Samantha. 2016. Migration, Work and Citizenship in the Enlarged European Union. New York: Routledge.

De Genova, Nicholas P. 2002. “Migrant 'Illegality' and Deportability in Everyday Life." Annual Review of Anthropology 31: 419-447.

European Commission. 2007. "Eurobarometer 67: Public Opinion in the European Union.” https://ec.europa.eu/commfrontoffice/publicopinion/archives/eb/ eb67/eb67_en.pdf.

Gallagher, Tom. 2009. Romania and the European Union: How the Weak Vanquished the Strong. Manchester: Manchester University Press.

Gammeltoft-Hansen, Thomas, and Ninna Nyberg Sørensen, eds. 2013. The Migration Industry and the Commercialization of International Migration. London: Routledge.

Ganti, Tejaswini. 2014. “Neoliberalism.” Annual Review of Anthropology 43: 89-104.

Garapich, Michal P. 2008. "The Migration Industry and Civil Society: Polish Immigrants in the United Kingdom before and after EU Enlargement.” Journal of Ethnic and Migration Studies 34 (5): 735-752.

Gershon, Ilana. 2014. "Selling Your Self in the United States.” PoLAR 37 (2): 281-295.

Gershon, Ilana. 2016. “'I’m Not a Businessman, I’m a Business, Man’: Typing the Neoliberal Self into a Branded Existence.” HAU: Journal of Ethnographic Theory 6 (3): 223-246.

Guano, Emanuela. 2010. "Taxpayers, Thieves, and the State: Fiscal Citizenship in Contemporary Italy.” Ethnos 75 (4): 471-495. 
Henig, David, and Nicolette Makovicky, eds. 2016. Economies of Favour After Socialism. Oxford: Oxford University Press.

Home Office. 2018. "Immigration Statistics, October to December 2017: How Many People Are Detained or Returned?” https://www.gov.uk/government/ publications/immigration-statistics-october-to-december-2017/how-many -people-are-detained-or-returned.

Hull, Matthew S. 2003. "The File: Agency, Authority, and Autography in an Islamabad Bureaucracy." Language \& Communication 23 (3-4): 287-314.

Hull, Matthew S. 2012. "Documents and Bureaucracy." Annual Review of Anthropology 41: 251-267.

IQLR (Institute for Quality of Life Research). 2017. "Social Conditions in Romania. Quality of Life: Current Situation and Perspectives for 2038.” Romanian Academy, Bucharest. https://bit.ly/2So6dWG.

Kochenov, Dimitry. 2006. "European Integration and the Gift of Second Class Citizenship.” eLaw Journal 13 (1): 209-224.

Larson, Jonathan L. 2008. “Ambiguous Transparency: Resumé Fetishism in a Slovak Workshop.” Ethnos 73 (2): 189-216.

Lipsky, Michael. 1980. Street-Level Bureaucracy: Dilemmas of the Individual in Public Services. New York: Russell Sage Foundation.

Makovicky, Nicolette, ed. 2016. Neoliberalism, Personhood, and Postsocialism: Enterprising Selves in Changing Economies. London: Routledge.

Martin, Isaac W., Ajay K. Mehrotra, and Monica Prasad. 2009. The New Fiscal Sociology: Taxation in a Comparative and Historical Perspective. Cambridge: Cambridge University Press.

Martin, Isaac W., and Monica Prasad. 2014. “Taxes and Fiscal Sociology.” Annual Review of Sociology 40: 331-345.

McGhee, Derek, Chris Moreh, and Athina Vlachantoni. 2019. "Stakeholder Identities in Britain's Neoliberal Ethical Community: Polish Narratives of Earned Citizenship in the Context of the UK's EU Referendum.” British Journal of Sociology 70 (4): 1104-1127.

Migration Observatory. 2014. “Commentary: Costs and 'Benefits.'” Migration Observatory, University of Oxford. https://migrationobservatory.ox.ac.uk/wpcontent/uploads/2016/03/Commentary-Costs_Benefits.pdf.

Millar, Kathleen M. 2014. “The Precarious Present: Wageless Labor and Disrupted Life in Rio de Janeiro, Brazil.” Cultural Anthropology 29 (1): 32-53.

Mindus, Patricia. 2017. “The Status of European Citizenship: An Overview.” In European Citizenship after Brexit: Freedom of Movement and Rights of Residence, 7-28. Cham: Springer.

Muehlebach, Andrea. 2013. "On Precariousness and the Ethical Imagination: The Year 2012 in Sociocultural Anthropology.” American Anthropologist 115 (2): 297-311.

Papadimitriou, Dimitris, and David Phinnemore. 2008. Romania and the European Union: From Marginalisation to Membership. New York: Routledge.

Parreñas, Rhacel Salazar. 2015. Servants of Globalization: Migration and Domestic Work. 2nd ed. Stanford, CA: Stanford University Press. 
Power, Michael. 1997. The Audit Society: Rituals of Verification. Oxford: Oxford University Press.

Riles, Annelise. 1998. "Infinity within the Brackets." American Ethnologist 25 (3): 378-398.

Roitman, Janet. 2007. "The Right to Tax: Economic Citizenship in the Chad Basin." Citizenship Studies 11 (2): 187-209.

Rose, Nikolas. 1999. Powers of Freedom: Reframing Political Thought. Cambridge: Cambridge University Press.

Scott, James C. 1985. Weapons of the Weak: Everyday Forms of Peasant Resistance. New Haven, CT: Yale University Press.

SFE (Student Finance England). 2016. "Assessing Eligibility Guidance: Higher Education Student Finance in England 2015/16 Academic Year.” https://www. practitioners.slc.co.uk/media/1118/201516-assessing-eligibility-guidance.pdf.

Strathern, Marilyn. 1991. Partial Connections. Savage, MD: Rowman \& Littlefield.

Strathern, Marilyn. 2000. "Introduction: New Accountabilities.” In Audit Cultures: Anthropological Studies in Audit, Ethics and the Academy, ed. Marilyn Strathern, 1-18. London: Routledge.

UKBA (UK Border Agency). 2008. "Living and Working in the UK: Rights and Responsibilities of Nationals from Bulgaria and Romania from 1 January 2007.” https://webarchive.nationalarchives.gov.uk/20081023110106/http://www.bia. homeoffice.gov.uk/sitecontent/documents/workingintheuk/livingandworkinga2.pdf.

Urciuoli, Bonnie. 2008. "Skills and Selves in the New Workplace." American Ethnologist 35 (2): 211-228.

Van Oort, Madison. 2015. "Making the Neoliberal Precariat: Two Faces of Job Searching in Minneapolis." Ethnography 16 (1): 74-94.

Vargas-Silva, Carlos, and Maria Fernández-Reino. 2019. "EU Migration to and from the UK." Migration Observatory, University of Oxford. https://migrationobservatory.ox.ac.uk/resources/briefings/eu-migration-to-and-from-the-uk/.

Vicol, Dora-Olivia, and Will Allen. 2014. "Bulgarians and Romanians in the British National Press.” Migration Observatory, University of Oxford. https://migrationobservatory.ox.ac.uk/resources/reports/bulgarians-romanians-in-press/.

Weber, Max. (1946) 1991. From Max Weber: Essays in Sociology. Trans. and ed. H. H. Gerth and C. Wright Mills. 2nd rev. ed. London: Routledge.

Yuval-Davis, Nira, Georgie Wemyss, and Kathryn Cassidy. 2018. "Everyday Bordering, Belonging and the Reorientation of British Immigration Legislation." Sociology 52 (2): 228-244. 